\title{
Gadoxetic Acid-Enhanced and Diffusion-Weighted Magnetic Resonance Imaging of Histologically Defined Early Hepatocellular Carcinoma
}

\author{
Nieun Seo', Myeong-Jin Kim', Young Nyun Park², Mi-Suk Park', Jin-Young Choi', Yong Eun Chung ${ }^{1}$ \\ 'Department of Radiology, Severance Hospital, Yonsei University College of Medicine, Seoul, Korea \\ ${ }^{2}$ Department of Pathology, Severance Hospital, Yonsei University College of Medicine, Seoul, Korea
}

Purpose: To describe the imaging features of histologically defined early hepatocellular carcinoma (eHCC) on gadoxetate disodium-enhanced MRI (EOB-MRI) and diffusion-weighted imaging (DWI).

Materials and Methods: We enrolled 173 surgically confirmed eHCCs in 119 patients examined by preoperative EOB-MRI and DWI between January 2006 and September 2017. The imaging features of preoperatively detected eHCCs were retrospectively analyzed by two radiologists. The clinical and imaging characteristics associated with false-negative detection were evaluated.

Results: Of the 173 eHCCs, 118 (68\%) in 78 patients were prospectively reported on preoperative EOB-MRI. After retrospective review, 17 eHCCs in 13 patients were additionally detected, with a per-lesion detection sensitivity of $78 \%$ (135/173). Thus, the imaging features of 135 eHCCs in 91 patients were analyzed. Most eHCCs exhibited hepatobiliary hypointensity $(90 \%, 122 / 135)$. Arterial phase hyperenhancement, washout, and capsule appearance were seen in 68 (50\%), 79 (59\%), and 11 (8\%) detected lesions, respectively. Diffusion restriction and fatty change were noted in 30 (22\%) and 39 (29\%) lesions, respectively; most eHCCs exhibited T1 and T2 isointensity (80 [59\%] and 89 [66\%], respectively). False-negative detection was associated with small lesion size $(<1 \mathrm{~cm}$ ), history of HCC treatment (odds ratio, 0.34 [95\% confidence interval, 0.13-0.92]), number of HCC lesions ( $\geq 2$; odds ratio, 0.08 [0.01-0.66]), and poor functional liver imaging score (<4; odds ratio, 0.13 [0.04$0.51])$.

Conclusions: Histologically defined eHCCs typically appear as hepatobiliary phase hypointensity. Detection sensitivity of eHCC may be affected by lesion size, history of HCC treatment, number of HCCs, and hepatobiliary enhancement.

Keywords: Hepatocellular carcinoma; Early diagnosis; Detection; Magnetic resonance imaging;

Diffusion-weighted imaging

\footnotetext{
Received: May 12, $2021 \quad$ Revised: June 17, $2021 \quad$ Accepted: June 19, 2021

Correspondence: Myeong-Jin Kim, MD, PhD

Department of Radiology, Severance Hospital, Yonsei University College of Medicine, 50-1 Yonsei-ro, Seodaemun-gu, Seoul 03722, Korea

Tel: +82-2-2228-7400 Fax:+82-2-2227-8337 E-mail: kimnex@yuhs.ac

This is an Open Access article distributed under the terms of the Creative Commons Attribution Non-Commercial License (http:// creativecommons.org/licenses/by-nc/4.0/) which permits unrestricted non-commercial use, distribution, and reproduction in any medium, provided the original work is properly cited.
} 


\section{Introduction}

Hepatocellular carcinoma (HCC) is a major cause of cancer-related mortality worldwide (1, 2). HCC develops via multistep carcinogenesis in a background of chronic liver disease, where an early HCC (eHCC) develops from a premalignant dysplastic lesion, then eventually to a progressed (moderately or poorly differentiated) HCC $(3,4)$. Early HCCs are histologically defined as vaguely nodular, well-differentiated HCCs with stromal invasion $(5,6)$, and are characterized by a lower risk of recurrence and higher 5 -year survival rate than progressed HCCs after treatment $(7,8)$. Therefore, the detection of eHCCs may help decrease mortality associated with HCC, and increase opportunities for curative treatment $(9,10)$.

The detection and characterization of eHCCs is more difficult than progressed HCCs, given that the former are usually small $(<2 \mathrm{~cm})$ and demonstrate fewer discernible findings via computed tomography (CT) and extracellular contrast-enhanced magnetic resonance imaging (MRI) (11-14). Diagnostic imaging via gadoxetate disodiumenhanced MRI (EOB-MRI) is superior to multiphase dynamic CT, as eHCCs are depicted as hypointense nodules in hepatobiliary phase (HBP) images (1519). However, the reported features of eHCCs on EOB$M R I$ are highly variable. Importantly, the incidence of arterial phase hyperenhancement (APHE), a hallmark for HCC diagnosis, ranges widely, from $13 \%$ (15) to $37 \%$ (16). Moreover, although diffusion-weighted imaging (DWI) has been recognized as an important tool in HCC diagnosis, especially in non-hypervascular HCCs (20-22), the appearance of eHCC by DWI is limited to only a few reports with relatively small subject numbers $(11,17)$.

Therefore, the aim of this study was to describe the imaging features of histologically defined eHCCs based on EOB-MRI and DWI in a relatively large number of subjects.

\section{Materials and Methods}

\section{Patients}

This retrospective study was approved by our Institutional Review Board, and the requirement for informed consent was waived. From January 2006 to September 2017, 218 adult patients who presented with at least one pathologically confirmed eHCC were identified from institutional electronic medical records. The study inclusion criteria were as follows: (a) patients who underwent surgery for eHCC; (b) those with preoperative EOB-MRI. Ninety-nine patients were excluded from the study for the following reasons: (a) biopsy-confirmed eHCC without surgery ( $n=3$; to exclude the possibility of biopsy tissue sampling an eHCC portion of a progressed HCC); (b) no contrast-enhanced liver MRI ( $n=19)$; (c) MRI using contrast agents other than gadoxetate disodium $(n=32)$; (d) interval between liver MRI and surgery $>3$ months ( $n$ $=40$ ); (e) $>5$ nodules in the pathological specimen ( $n$ $=5$; due to difficulty in correlating the radiological and pathological findings). Thus, 119 patients were included in our study (Fig. 1). The median interval between MRI and surgery was 26 days (range, $0-86$ days).

\section{8 patients who had at least one pathologically proven early HCC between January 2006 and September 2017}

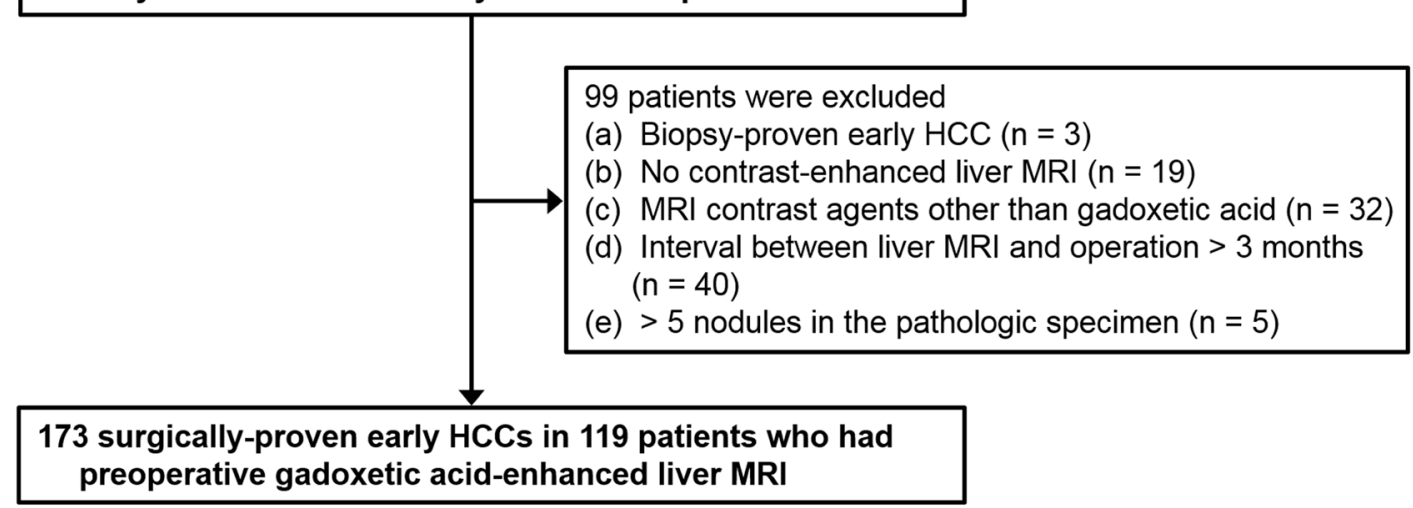

Fig. 1. Flow diagram of the patient enrollment process. 
Electronic medical records were retrospectively reviewed for clinical findings and laboratory data. Clinical findings included patient characteristics, chronic liver disease etiology, history of HCC treatment, and type of liver surgery. Laboratory data included serum albumin, total bilirubin, aspartate transaminase, alanine transaminase, and alpha fetoprotein. The Child-Pugh score and albuminbilirubin (ALBI) grade were both calculated to evaluate the hepatic function of the study population (23-25).

\section{Pathological diagnosis}

Pathological examination was performed by a senior liver pathologist (with more than 20 years of experience in hepatic pathology), together with one or two residents or a fellow. The pathological reports included the fibrosis grade of the non-tumor-bearing liver parenchyma and the location, size, and number of eHCCs and progressed HCCs. Diagnosis of eHCC was based on the established histological criteria of a small, well-differentiated HCC of a vaguely nodular type, with combinations of the following histological features: (a) increased cell density more than two times that of the surrounding parenchyma, with an increased nuclear/cytoplasm ratio and irregular thin-trabecular pattern; (b) varying numbers of intratumoral portal tracts; (c) pseudoglandular pattern; (d) fatty change; (e) varying numbers of unpaired arteries (6). Importantly, the presence of stromal invasion was useful for differentiating high-grade dysplastic nodules from eHCCs $(6,26)$. When morphologic criteria, such as stromal invasion, were difficult to assess, a panel of immunohistochemical markers were used to establish the diagnosis, including glypican-3, heat shock protein 70, and glutamine synthetase; eHCC was diagnosed when two or more immune-markers were positive (26).

\section{Magnetic resonance imaging}

Liver MRI was performed using a 3.0-T (MAGNETOM Tim Trio, Siemens Healthineers; Intera Achieva or Ingenia, Philips Healthcare) or a 1.5-T system (Intera Achieva or Ingenia, Philips Healthcare). Routine liver MRI sequences included dual-echo spoiled gradient-echo T1-weighted inphase and opposed-phase images, multi-shot and singleshot turbo spin-echo T2-weighted images (T2WI), singleshot echo planar DWI with b values of 50,400, and $800 \mathrm{sec} / \mathrm{mm}^{2}$, and dynamic T1-weighted images (T1WI).
Dynamic fat-suppressed spoiled gradient-echo T1WI was acquired before and after gadoxetate disodium injection (Primovist, Bayer Pharma AG) at a dose of $0.1 \mathrm{~mL} / \mathrm{kg}(0.025$ $\mathrm{mmol} / \mathrm{kg}$ ), followed by a $20-\mathrm{mL}$ saline flush at an injection rate of $1 \mathrm{~mL} / \mathrm{sec}$. To determine the timing of the arterial phase, a bolus-tracking method was used. Subsequent dynamic phases were acquired at approximately $30 \mathrm{sec}$ intervals; each dynamic phase required $16-22 \mathrm{sec}$. The HBP images were obtained 20 min after contrast injection.

\section{Image analysis}

The detection sensitivity of eHCC was calculated from both prospective and retrospective reading sessions. A study coordinator (an abdominal radiologist with 5 years of experience in liver imaging) performed radiologicpathologic correlations (through review of the MRI and pathological reports) by matching the size and location of the hepatic lesions. Prospective detection sensitivity was determined from the preoperative reports of MRI examinations conducted by one of five faculty radiologists (all with more than 5 years of experience in abdominal $M R I)$, together with one or two residents and/or fellows. A lesion was defined as "detected" when an eHCC, documented on the pathologic report, was identified and mentioned in the preoperative MRI. The original radiologic impressions of histologically confirmed eHCCs were divided into one of the following six categories: definite benign, probably benign, indeterminate, probably HCC, definitely HCC, or other malignancy such as metastasis. Thereafter, retrospective analyses were performed by the study coordinator to identify missed or unreported eHCCs; any lesions identified were included in the calculation of overall detection sensitivity and review of MRI findings.

To investigate whether the detection sensitivity was affected by image quality or hepatic function, two abdominal radiologists, with 25 and 5 years of experience in liver MRI, reviewed the MRI using a picture archiving and communication system (Centricity version 4, GE healthcare). The image quality of the HBP of EOB-MRI was evaluated using the functional liver imaging score (FLIS), previously validated in liver transplant recipients (27). The FLIS was calculated as the sum of the following three parameters: liver parenchymal enhancement relative to the kidney (EnQS: 0, hypointense; 1, isointense; 2, hyperintense); biliary contrast excretion (ExQS: 0, no 
excretion; 1, excretion into peripheral intrahepatic bile ducts; 2, excretion into the common hepatic duct, common bile duct, or duodenum); and signal intensity (SI) of the portal vein relative to the liver (PVsQS: 0, hyperintense; 1, isointense; 2 , hypointense). A higher FLIS indicates better image quality of the HBP. The image qualities of other sequences, including dynamic $\mathrm{T} 1 \mathrm{WI}, \mathrm{T} 2 \mathrm{WI}$, and $\mathrm{DWl}$, were graded using a four-point scale: 1, poor; 2, fair; 3, good; and 4, excellent. Subsequently, the same two radiologists independently evaluated the MRI features of the detected eHCCs. The reviewers were informed of the size and location of the detected eHCCs via series/image numbers and arrows on the picture archiving and communication system. Each MRI finding was evaluated for: the presence of fatty change, APHE, washout, capsule appearance, and SI on pre-contrast T1WI, T2WI, DWI, and HBP. The definition of each finding was based on the 2017 Liver Imaging Reporting and Data System (28). For example, washout was determined from the portal venous phase only. The presence of fatty change was determined by comparison of in- and opposed-phase T1-weighted gradient-echo images. The presence of a smooth hypointense rim on HBP (HBP capsule appearance) was noted in addition to the conventional capsular appearance (29). Capsular appearance was considered positive when it appeared around at least two-thirds of the tumor border (29, 30). Discrepancies between reviewers were resolved by consensus review, and the consensus data were used for analysis. Original data from the independent review were used to calculate interobserver agreement.

\section{Statistical analysis}

Both per-patient and per-lesion detection sensitivities were calculated. If all eHCCs were detected in a patient, we considered this "detected" on a per-patient basis. If any eHCC was missed in a patient, we classified this as "undetected" in terms of per-patient sensitivity. Both preoperatively reported lesions and retrospectively identified lesions were regarded as detected lesions for image review, as well as for the calculation of detection sensitivity. The per-lesion detection sensitivity was also calculated according to the size of the eHCC. For perlesion analysis, generalized estimating equations were used to adjust for possible clustering effects caused by multiple lesions in a patient. Detection sensitivities were compared among different sized groups of eHCC using logistic regression with generalized estimating equations. Baseline patient demographics and MRI quality were compared between patients with and without falsenegative lesions using independent t-tests for continuous variables and Pearson's chi-squared test or Fisher's exact test for categorical variables. Per-patient analyses of factors affecting the detection of eHCCs were performed using logistic regression. Multivariate analysis was performed for significant factors identified by univariate analysis. The interobserver agreement regarding MRI quality and imaging findings of detected eHCCs were assessed using weighted $\mathrm{K}$ statistics as follows: $\mathrm{K}$ values $<0.20$, poor; 0.21-0.40, fair; 0.41-0.60, moderate; 0.610.80, good; 0.81-1.00, excellent (31). Statistical analyses were performed using SPSS v23.0 software (IBM Corp.). P values $<0.05$ were considered statistically significant.

\section{Results}

\section{Detection rate of early hepatocellular carcinoma}

The prospective per-patient and per-lesion detection sensitivities of eHCCs from preoperative MRI reports were $66 \%(78 / 119)$ and $68 \%(118 / 173)$, respectively. The radiologic impressions of 118 originally detected lesions were as follows: HCC, $52 \%(n=61)$; probably HCC, $21 \%(n=25)$; indeterminate, $25 \%(n=29)$; probably benign, $1 \%(n=1)$; metastasis in patients with history of other malignancy, $2 \%(n=2)$. After retrospective review, 17 eHCCs were additionally identified in 13 patients. Thus, retrospective per-patient and per-lesion detection sensitivities were 77\% (91/119) and 78\% (135/173), respectively. Per-lesion sensitivity increased with eHCC size: < 1-cm lesions, 63\% (35/56); 1 - to 2-cm lesions, $82 \%(72 / 88) ; \geq 2$-cm lesions, 97\% (28/29). Per-lesion detection sensitivity differed significantly between $<1-\mathrm{cm}$ and $\geq 1-\mathrm{cm}$ lesions ( $56 \%$ and $85 \%$, respectively; $P=$ 0.001 ). Detected eHCCs (mean \pm standard deviation, 1.5 $\pm 0.6 \mathrm{~cm}$ ) were significantly larger than undetected eHCCs $(1.0 \pm 0.5 \mathrm{~cm} ; \mathrm{P}<0.001)$.

\section{Patients and magnetic resonance imaging quality}

The comparisons of the patient demographics and MRI quality between patients with and without falsenegative findings are summarized in Table 1. Patients with 
Table 1. Patient characteristics and magnetic resonance image quality

\begin{tabular}{|c|c|c|c|c|c|c|c|}
\hline \multirow{3}{*}{ qua } & \multirow{3}{*}{$\begin{array}{l}\text { With FN } \\
(n=28)\end{array}$} & \multirow{3}{*}{$\begin{array}{c}\text { Without FN } \\
(n=91)\end{array}$} & \multirow{3}{*}{$P$ value } & \multirow{2}{*}{\multicolumn{2}{|c|}{$\begin{array}{l}\text { With FN } \\
(n=28)\end{array}$}} & \multirow[b]{2}{*}{$\begin{array}{c}\text { Without FN } \\
(n=91)\end{array}$} & \multirow[b]{2}{*}{$P$ value } \\
\hline & & & & & & & \\
\hline & & & & \multicolumn{2}{|l|}{$\overline{A L B I}$ grade } & & \multirow[t]{6}{*}{0.650} \\
\hline Clinicopathologic findings & & & & 1 & $14(50)$ & $50(55)$ & \\
\hline Age (years) & $65.0 \pm 6.9$ & $61.7 \pm 8.2$ & 0.058 & 2 & $9(32)$ & $31(34)$ & \\
\hline Sex & & & 0.771 & 3 & $5(18)$ & $10(11)$ & \\
\hline Male & $23(82)$ & $77(85)$ & & \multicolumn{3}{|l|}{ MR image quality } & \\
\hline Female & $5(18)$ & $14(15)$ & & \multicolumn{3}{|l|}{ Hepatobiliary phase } & \\
\hline Cause of CLD & & & 0.515 & EnQS & & & 0.038 \\
\hline HBV & $22(79)$ & $73(80)$ & & 0 & $5(18)$ & $3(3)$ & \\
\hline $\mathrm{HCV}$ & $4(14)$ & $7(8)$ & & 1 & $4(14)$ & $10(11)$ & \\
\hline Alcoholic & $1(4)$ & $9(10)$ & & 2 & $19(68)$ & $78(86)$ & \\
\hline Others & $1(4)$ & $2(2)$ & & \multicolumn{2}{|l|}{ EXQS } & & 0.336 \\
\hline History of HCC & & & 0.014 & 0 & $2(7)$ & $2(2)$ & \\
\hline No & $16(57)$ & $73(80)$ & & 1 & $4(14)$ & $8(9)$ & \\
\hline Yes & $12(43)$ & $18(20)$ & & 2 & $22(79)$ & $81(89)$ & \\
\hline Type of surgery & & & 0.008 & PVsQS & & & 0.217 \\
\hline Resection & $12(43)$ & $64(70)$ & & 0 & $2(7)$ & $2(2)$ & \\
\hline LT & $16(57)$ & $27(30)$ & & 1 & $6(21)$ & $11(12)$ & \\
\hline Pathologic cirrhosis & & & 0.054 & 2 & $20(71)$ & $78(86)$ & \\
\hline No & $3(11)$ & $26(29)$ & & FLIS & & & 0.004 \\
\hline Yes & $25(89)$ & $65(71)$ & & $0-3$ & $8(29)$ & $6(7)$ & \\
\hline Number of $\mathrm{HCC}$ & & & 0.003 & $4-6$ & $20(71)$ & $85(93)$ & \\
\hline One & $1(4)$ & $27(30)$ & & Dynamic phase & & & 0.464 \\
\hline Two & $10(36)$ & $37(41)$ & & Poor-fair & $6(21)$ & $14(15)$ & \\
\hline Three or more & $17(61)$ & $27(30)$ & & Good-excellent & $22(79)$ & $77(85)$ & \\
\hline Number of eHCC & & & 0.014 & $\mathrm{~T} 2 \mathrm{Wl}$ & & & 0.032 \\
\hline One & $15(54)$ & $72(79)$ & & Poor-fair & $5(18)$ & $4(4)$ & \\
\hline Two & $5(18)$ & $12(13)$ & & Good-excellent & $23(82)$ & $87(96)$ & \\
\hline Three or more & $8(29)$ & $7(8)$ & & DWI & & & 0.130 \\
\hline Presence of progressed HCC & & & 0.742 & Poor-fair & $7(25)$ & $11(12)$ & \\
\hline No & $8(29)$ & $29(32)$ & & Good-excellent & $21(75)$ & $80(88)$ & \\
\hline Yes & $20(71)$ & $62(68)$ & & \multicolumn{4}{|c|}{ The data are expressed as means \pm standard deviations. } \\
\hline Largest size of eHCC $(\mathrm{cm})$ & $1.3 \pm 0.8$ & $1.4 \pm 0.7$ & 0.451 & \multirow{10}{*}{\multicolumn{4}{|c|}{$\begin{array}{l}\text { The data in parentheses are percentages. Percentages may not sum to } 100 \% \\
\text { because of rounding. } \\
\text { FN, false-negative; CLD, chronic liver disease; HBV, hepatitis B virus; HCV, } \\
\text { hepatitis C virus; HCC, hepatocellular carcinoma; LT, liver transplantation; } \\
\text { eHCC, early hepatocellular carcinoma; AST, aspartate transaminase; ALT, } \\
\text { alanine transaminase; AFP, alpha fetoprotein; ALBI, albumin-bilirubin; EnQS, } \\
\text { enhancement quality score; ExQS, excretion quality score; PVsQS, portal vein } \\
\text { sign quality score; FLIS, functional liver imaging score; T2WI, T2-weighted } \\
\text { imaging; DWI, diffusion-weighted imaging. }\end{array}$}} \\
\hline Albumin ( $g / d L)$ & $3.7 \pm 0.8$ & $3.8 \pm 0.7$ & 0.746 & & & & \\
\hline Total bilirubin (mg/dL) & $1.4 \pm 1.1$ & $1.0 \pm 0.7$ & 0.150 & & & & \\
\hline AST (IU/L) & $42.7 \pm 20.1$ & $51.0 \pm 38.2$ & 0.273 & & & & \\
\hline ALT (IU/L) & $34.8 \pm 22.4$ & $47.1 \pm 41.6$ & 0.138 & & & & \\
\hline AFP (ng/mL) & $126.1 \pm 369.5$ & $238.6 \pm 1081.6$ & 0.591 & & & & \\
\hline Child-Pugh score & & & 0.188 & & & & \\
\hline A & $20(71)$ & $76(84)$ & & & & & \\
\hline B & $6(21)$ & $14(15)$ & & & & & \\
\hline $\mathrm{C}$ & $2(7)$ & $1(1)$ & & & & & \\
\hline
\end{tabular}

Table 1. Continued

The data are expressed as means \pm standard deviations.

because of rounding alanine transaminase; AFP, alpha fetoprotein; ALBI, albumin-bilirubin; EnQS, enhancement quality score; ExQS, excretion quality score; PVsQS, portal vein sign quality score; FLIS, functional liver imaging score; T2WI, T2-weighted

Continued 
a false-negative eHCC detection had a more frequent history of HCC treatment $(P=0.014)$ and underwent liver transplantation more frequently than resection $(P=0.008)$, compared to those without. In addition, the multiplicity of both total $(P=0.003)$ and early $(P=0.014)$ HCCs was greater in patients with a false-negative detection. Most patients with eHCCs had progressed HCCs $(82 / 119,69 \%)$ in addition to eHCC, but the presence of progressed HCCS did not differ significantly between patients with and without a false negative detection of eHCC $(P=0.742)$. Liver function, determined by the Child-Pugh score, ALBI grade, and laboratory findings, did not differ significantly between the groups ( $P s \geq 0.138$ ). Hepatobiliary phase image qualities, determined by EnQS and FLIS, were significantly higher in patients without false-negative detection ( $P=0.038$ and $P=0.004$, respectively). Similarly, the image quality of $\mathrm{T} 2 \mathrm{WI}$ were significantly higher in patients without false-negative detection $(P=$ $0.032)$, but those of dynamic phase and DWI did not differ significantly between the groups $(P=0.464$ and $P=0.130$, respectively).

Interobserver agreement of MRI quality was good to excellent (EnQS, $\mathrm{K}=0.757$ [95\% confidence interval (95\% Cl), 0.644-0.870]; ExQS, $\mathrm{K}=0.824$ [0.699-0.950]; PVsQS, $\mathrm{K}=0.834$ [0.705-0.962]; dynamic phase, $\mathrm{K}=0.849$ [0.770-0.928]; T2WI, $\mathrm{K}=0.675$ [0.556-0.795]; and DWI, $\mathrm{K}=0.730[0.632-0.829])$.

\section{Magnetic resonance imaging findings}

The imaging features of eHCCs on EOB-MRI and DWI are presented in Table 2 and Figs. 2-4. The imaging features of undetected eHCCs $(n=38)$ were regarded to show negative findings or isointense SI. Fatty change was noted in $29 \%$ of detected $(n=135)$ and $23 \%$ of total ( $n$ $=173$ ) eHCCs. Most eHCCs showed hypointensity on HBP ( $90 \%$ and $71 \%$ of detected and total eHCCs, respectively), while most detected eHCCs showed isointensity on T1WI (59\%) and T2WI (66\%). Arterial phase hyperenhancement was present in $50 \%$ and $39 \%$ of detected and total eHCCs, respectively. Washout and capsule appearance in the dynamic phase were observed in $59 \%$ and $8 \%$ of detected eHCCs, and $46 \%$ and $6 \%$ of total eHCCs, respectively. Diffusion restriction was observed in $22 \%$ and $17 \%$ of detected and total eHCCs, respectively. Among the 30 eHCCs showing diffusion restriction, 29 (97\%) showed
APHE. The interobserver agreement of MRI findings was good to excellent ( $\kappa, 0.716-0.894)$.

\section{Factors associated with the false-negative detection of early hepatocellular carcinoma}

Factors affecting the detection of eHCCs are given in Table 3. Univariate analysis showed that history of HCC treatment, type of surgery, number of total HCCs and eHCCS, EnQS, FLIS, and quality of T2WI were significant factors affecting the detection of eHCCs. Multivariate analysis revealed that history of HCC treatment (odds ratio, $0.34[95 \% \mathrm{Cl}, 0.31-0.92]$, number of total HCCs ( $\geq 2$; odds ratio, 0.08 [0.01-0.66]), and poor FLIS $(<4$; odds ratio, 0.13 [0.04-0.51]) were independent factors negatively affecting the detection of eHCCs.

\section{Discussion}

Our results showed per-patient and per-lesion sensitivities for the detection of eHCCs of $66 \%$ and $68 \%$ on the prospective interpretation and $77 \%$ and $78 \%$ on the retrospective analysis of EOB-MRI. Early HCC on retrospectively analysis was most commonly depicted by HBP hypointensity (90\%), with more common presentation of APHE (50\%) and washout appearance (59\%) than fatty change $(29 \%)$, diffusion restriction $(22 \%)$, and capsule appearance (8\%). False-negative detection of eHCCs was associated with lesion size, history of HCC treatment, number of HCCS, and the degree of hepatobiliary enhancement.

Our study demonstrates the usefulness of HBP of EOBMRI for detecting eHCCs as hypointensity. In our series, $90 \%$ and $71 \%$ of identifiable and total eHCCs showed HBP hypointensity, respectively; comparable with Sano et al. (15) and Kim et al. (17) (97\% and 76\%, respectively). The high sensitivity of HBP hypointensity for detecting eHCC may be explained by the decrease in OATP8 expression occurring prior to hemodynamic alteration, such as neoarterialization or reduced portal blood flow (15, 17, 32).

Interestingly, in our series, $50 \%$ and $39 \%$ of detected and total eHCCs showed APHE, compared to just $29 \%$ and $13 \%$ of total eHCCs reported by Kim et al. (17) and Sano et al. (15), respectively. Additionally, fatty change was less common (29\%) in our study than reported by 
Table 2. Magnetic resonance imaging findings of early hepatocellular carcinoma

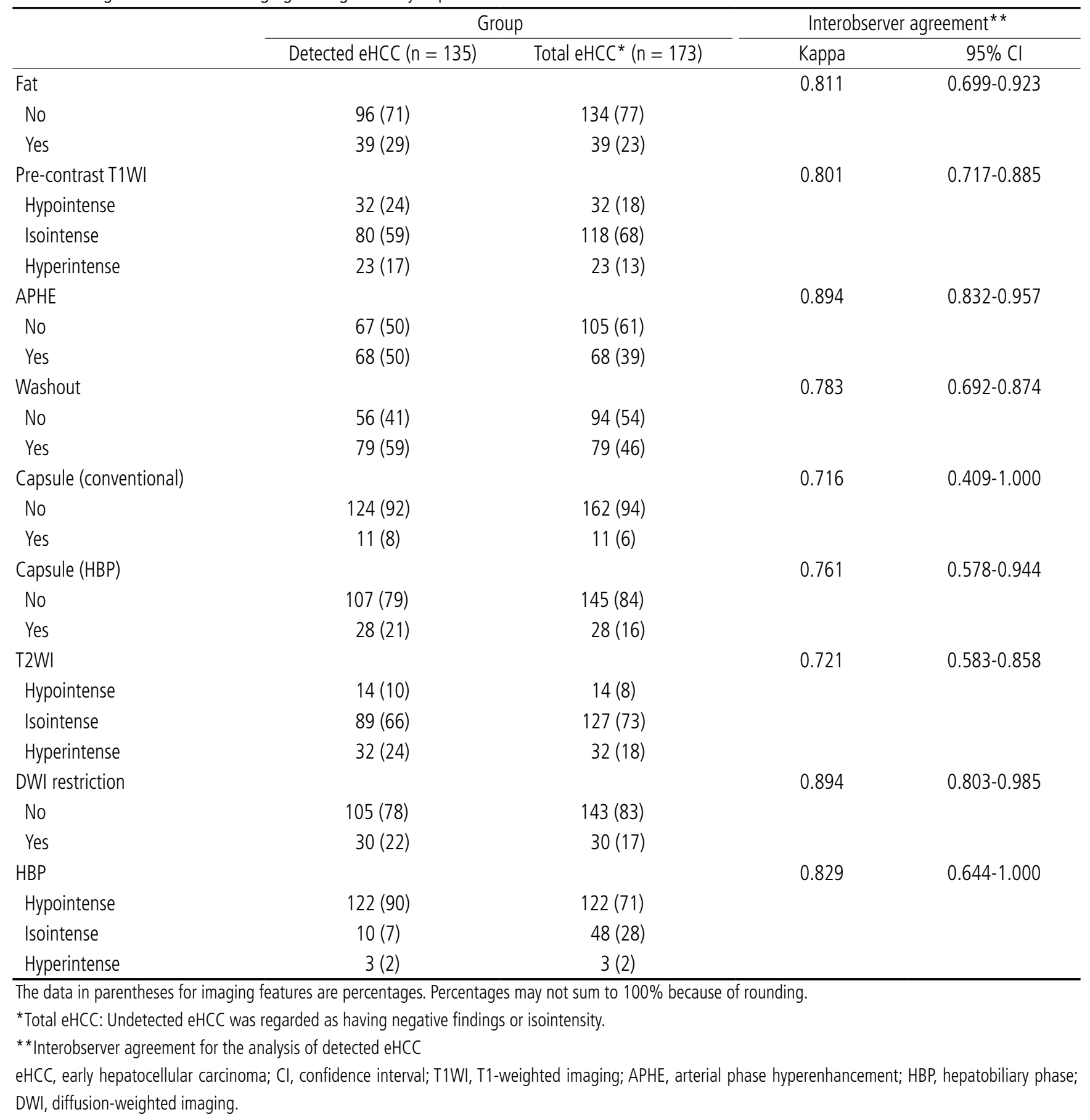

Sano et al (53\%) (15). This discrepancy may be attributed to the different diagnostic criteria applied by pathologists across institutions. We only included the surgically resected lesions determined as eHCC by an expert pathologist, based on the established histological criteria $(6,26)$. Therefore, our results indicate that eHCCs may also show hypervascularization detectable on EOB-MRI. In our experience, EOB-MRI may be advantageous for identifying APHE in eHCCs, by demonstrating HBP hypointensity, making it easier to match small arterially hyperenhancing lesions with true lesions. Conversely, on CT or extracellular agent-enhanced MRI, subtle hyperenhancing lesions may 


\section{KJAR}

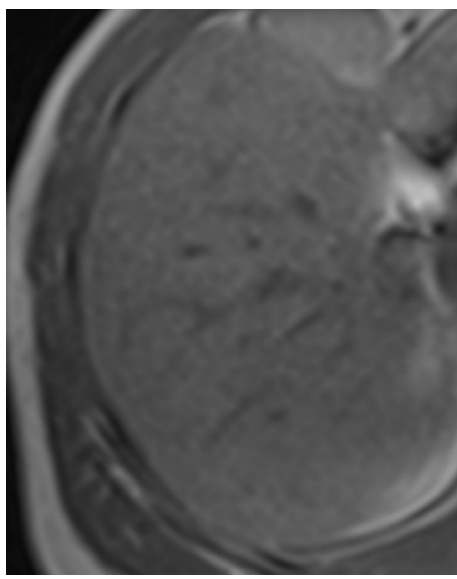

A

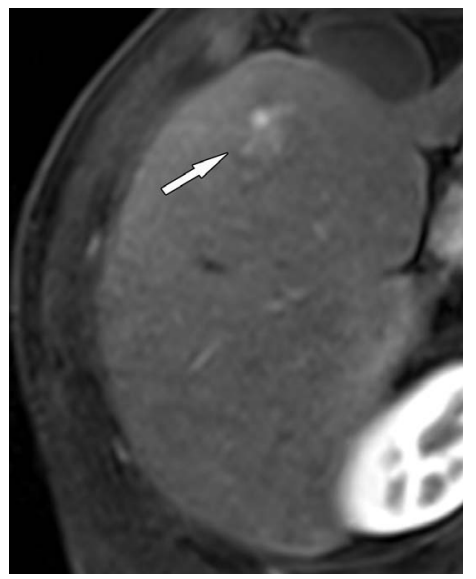

D

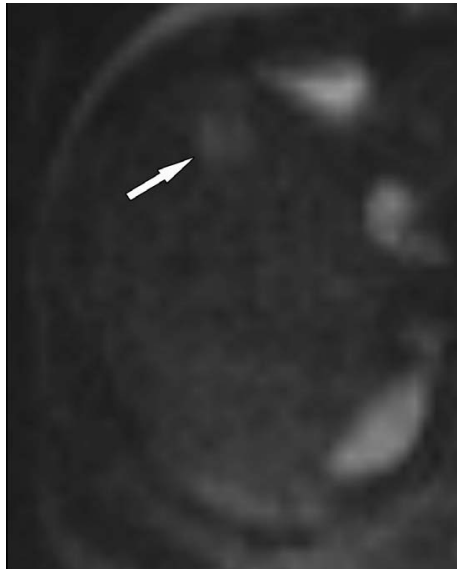

G

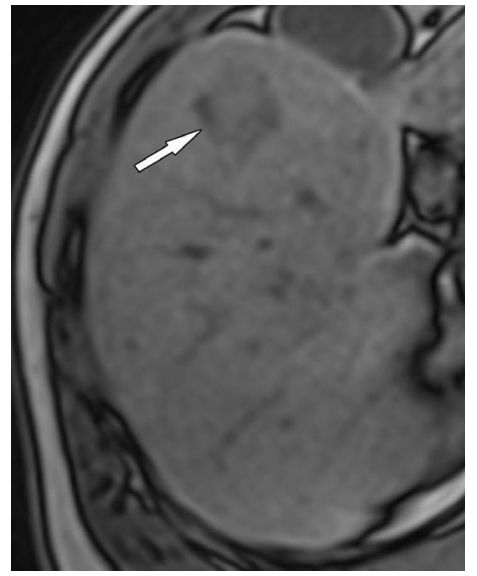

B

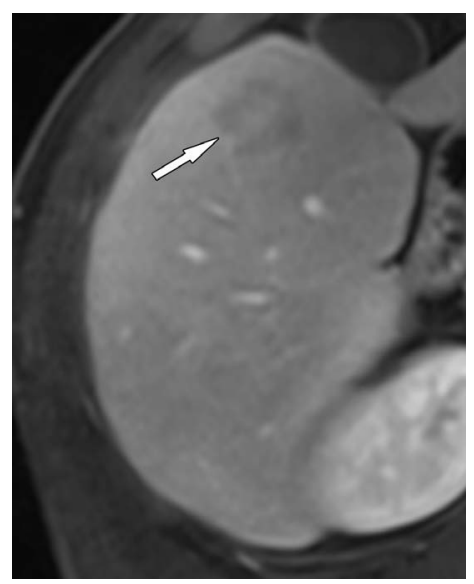

$\mathrm{E}$

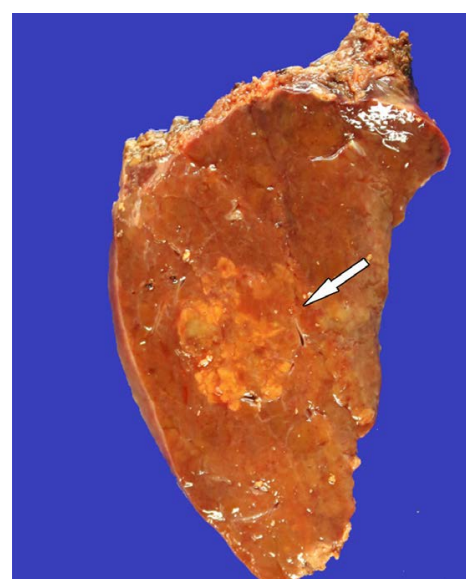

H

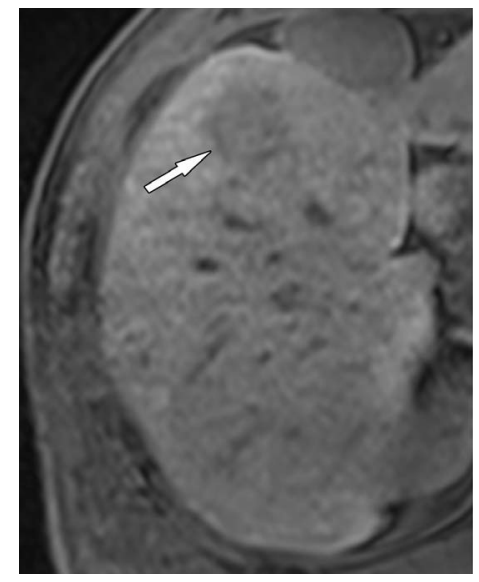

C

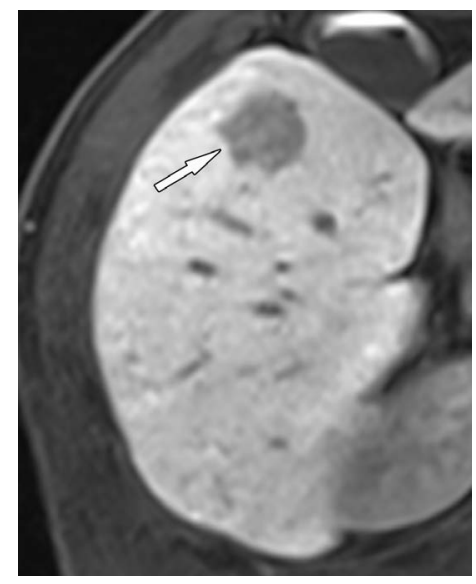

$\mathrm{F}$

Fig. 2. Magnetic resonance images of an early hepatocellular carcinoma lesion in a 44-year-old man who underwent hepatic resection. (A) The in-phase and (B) opposed-phase T1-weighted magnetic resonance images show fatty change within the tumor (arrow) in segment V. (C) The precontrast T1-weighted image shows hypointensity of the tumor (arrow). (D) The hepatic arterial phase image shows hyperenhancement (arrow), and (E) the portal venous phase image reveals washout of the tumor (arrow). (F) The hepatobiliary phase image shows avid hypointensity of the tumor (arrow). (G) The mass shows mild hyperintensity (arrow) on the diffusion-weighted image $\left(b=800 \mathrm{sec} / \mathrm{mm}^{2}\right)$. (H) The gross surgical specimen shows a 2.2-cm early hepatocellular carcinoma lesion (arrow). 


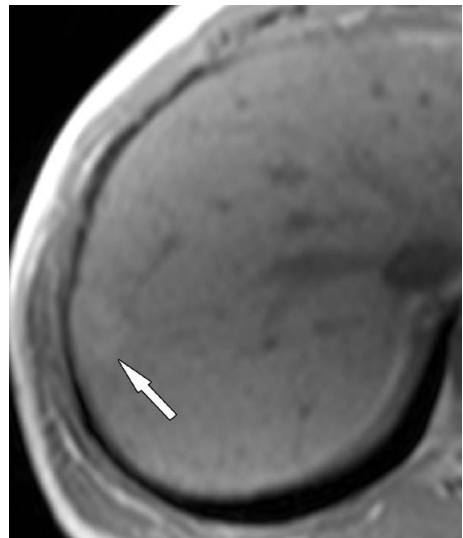

A

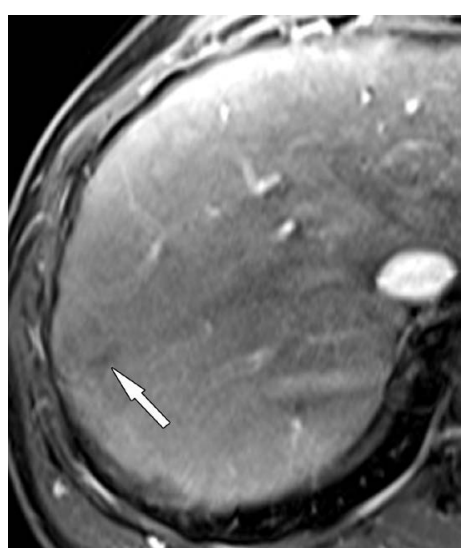

D

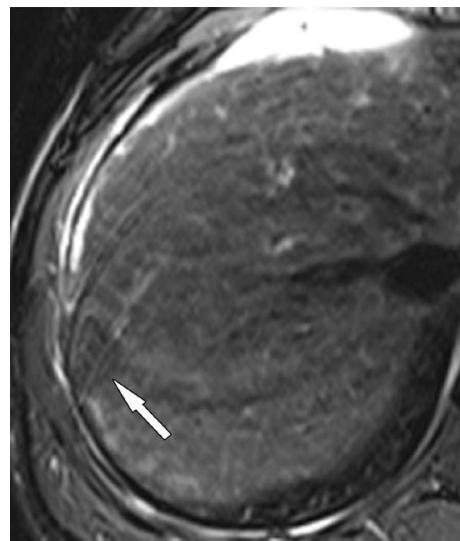

G

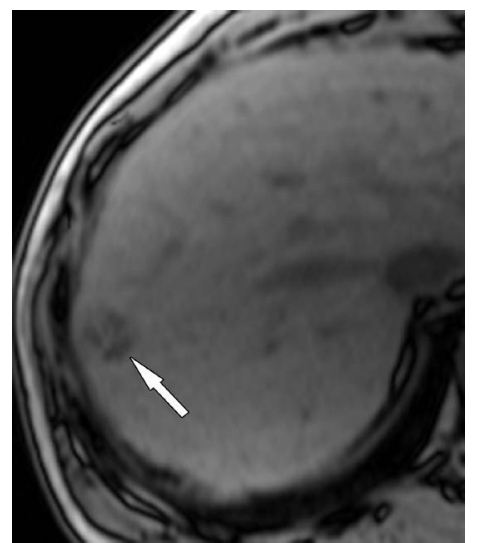

B

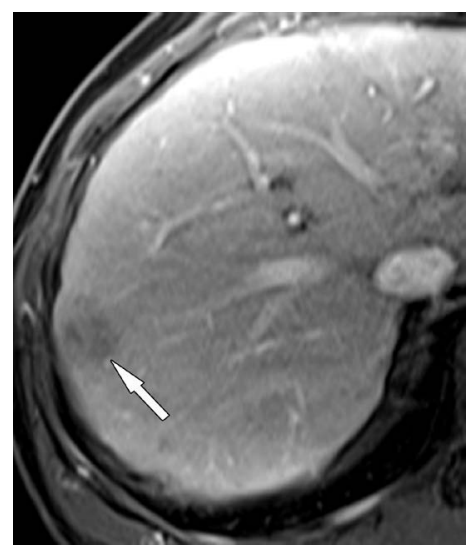

$E$

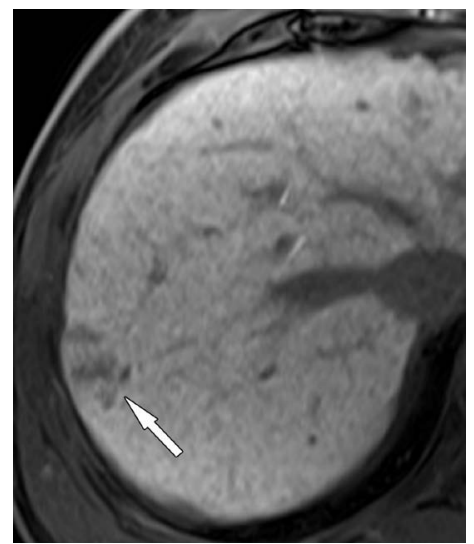

$\mathrm{H}$

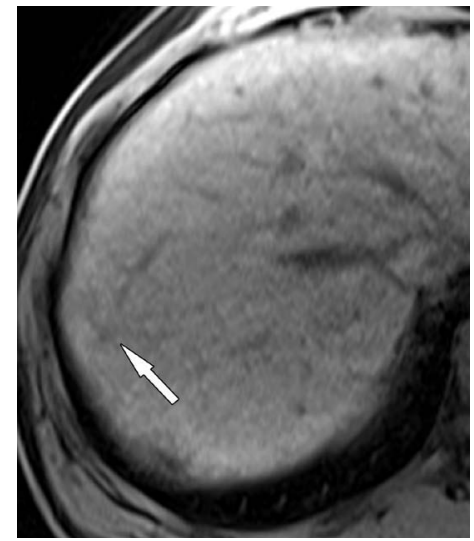

C

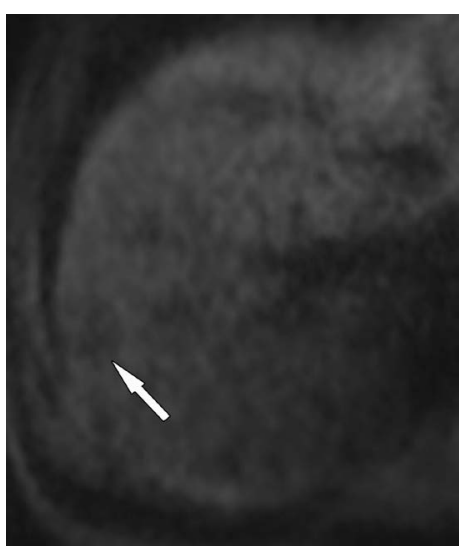

$\mathrm{F}$

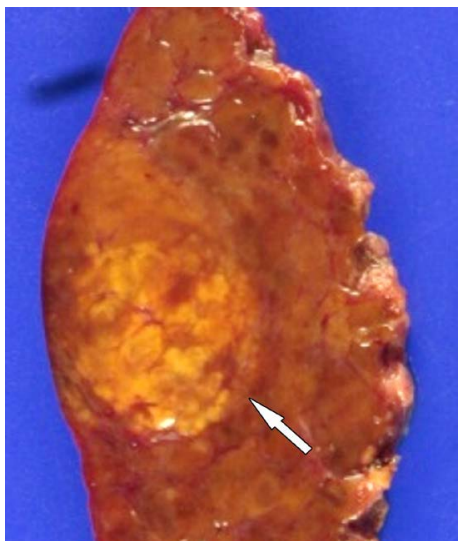

Fig. 3. Magnetic resonance images of an early hepatocellular carcinoma lesion in a 57-year-old woman who underwent hepatic resection. (A) The in-phase and (B) opposed-phase T1-weighted magnetic resonance images show fatty change within the tumor (arrows). Compared with (C) the pre-contrast T1-weighted image, the tumor shows no definite hyperenhancement (arrow) on (D) the hepatic arterial phase image. (E) The portal venous phase demonstrates hypointensity of the tumor (arrow). The tumor shows hypointensity (arrows) on (F) the diffusion-weighted image ( $\left.b=800 \mathrm{sec} / \mathrm{mm}^{2}\right)$ and (G) T2-weighted image. (H) The hepatobiliary phase image shows hypointensity of the tumor (arrow). (I) The gross surgical specimen shows a 2.2-cm early hepatocellular carcinoma lesion (arrow). 


\section{KJAR}

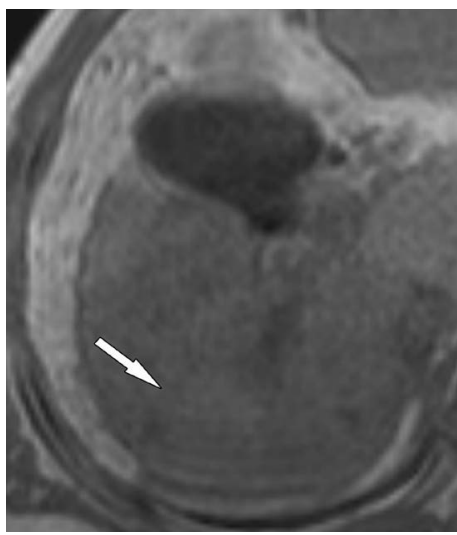

A

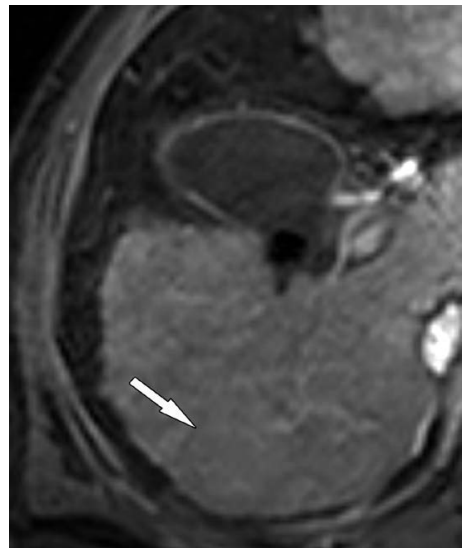

D

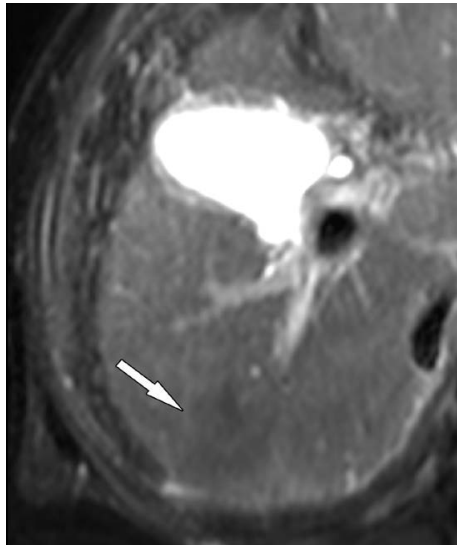

G

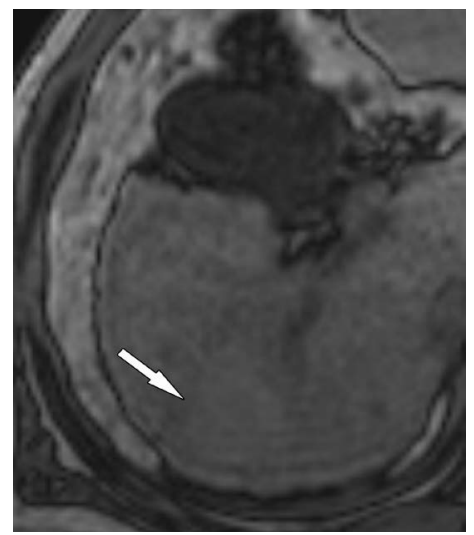

B

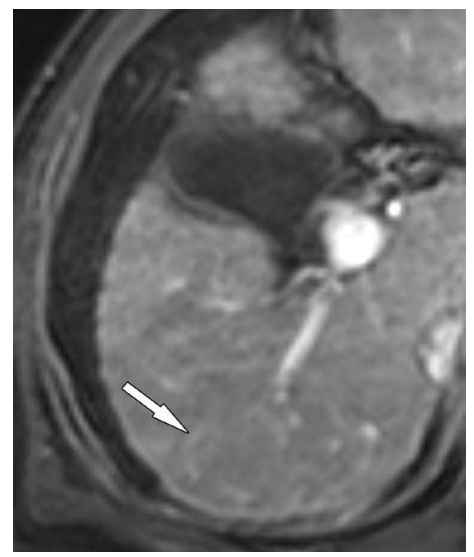

$E$

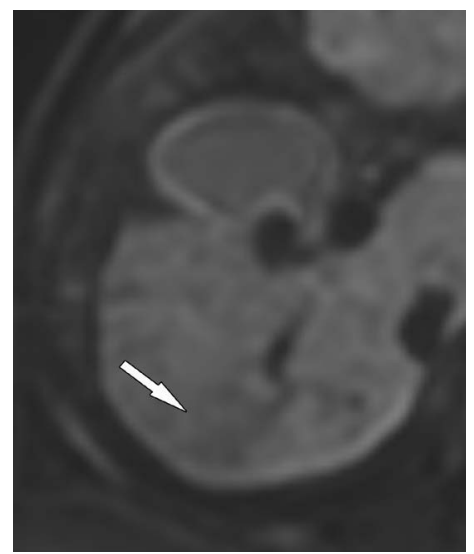

$\mathrm{H}$

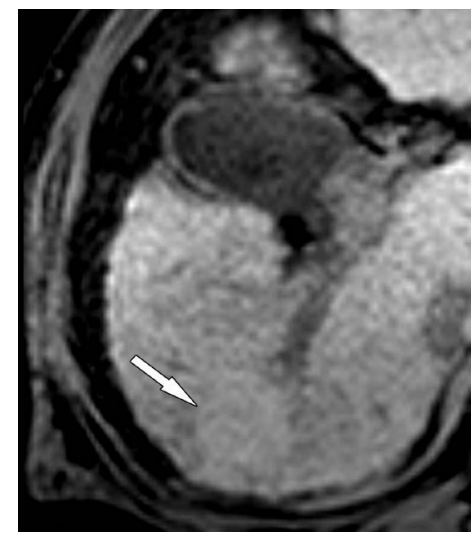

C

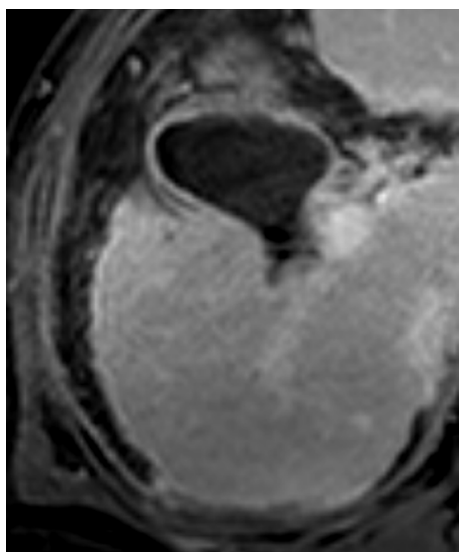

$\mathrm{F}$

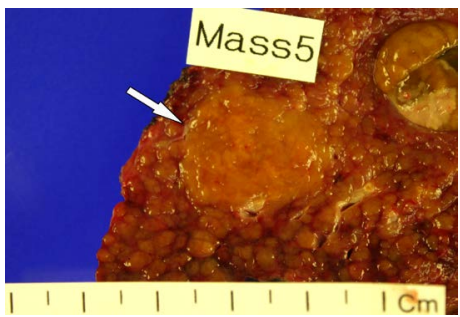

|

Fig. 4. Magnetic resonance images of an early hepatocellular carcinoma lesion in a 54-year-old woman who underwent liver transplantation. This lesion was not prospectively detected on a radiologic report, but was identified after retrospective review. (A) The in-phase and (B) opposedphase T1-weighted images show no fatty change within the tumor (arrow). (C) The pre-contrast T1-weighted image shows mild hyperintensity of the tumor (arrow). (D) The hepatic arterial phase image and (E) portal venous phase demonstrate no arterial phase hyperenhancement or washout of the tumor (arrows). The tumor shows isointensity on (F) the hepatobiliary phase. Note that the quality of the hepatobiliary phase was poor, with a functional liver imaging score of 0 . The tumor shows hypointensity (arrows) on (G) the T2-weighted image and (H) diffusionweighted image $\left(b=800 \mathrm{sec} / \mathrm{mm}^{2}\right)$. (I) The gross surgical specimen shows a 2-cm early hepatocellular carcinoma lesion (arrow). 
Table 3. Factors associated with the false-negative detection of early hepatocellular carcinoma: Per-patient analysis

\begin{tabular}{|c|c|c|c|c|c|c|}
\hline & \multicolumn{3}{|c|}{ Univariate Analysis } & \multicolumn{3}{|c|}{ Multivariate Analysis } \\
\hline & Odds ratio & $95 \% \mathrm{Cl}$ & $P$ value & Odds ratio & $95 \% \mathrm{Cl}$ & P value \\
\hline Age & 0.95 & $0.89-1.00$ & 0.062 & & & \\
\hline \multicolumn{7}{|l|}{ History of HCC } \\
\hline \multicolumn{7}{|l|}{ No } \\
\hline Yes & 0.33 & $0.13-0.82$ & 0.016 & 0.34 & $0.13-0.92$ & 0.033 \\
\hline \multicolumn{7}{|l|}{ Type of surgery } \\
\hline \multicolumn{7}{|l|}{ Resection } \\
\hline LT & 0.32 & $0.13-0.76$ & 0.010 & & & \\
\hline \multicolumn{7}{|c|}{ Pathologic cirrhosis } \\
\hline \multicolumn{7}{|l|}{ No } \\
\hline Yes & 0.30 & $0.08-1.08$ & 0.065 & & & \\
\hline \multicolumn{7}{|l|}{ No. of HCC } \\
\hline \multicolumn{7}{|l|}{ One } \\
\hline Two or more & 0.09 & $0.01-0.68$ & 0.020 & 0.08 & $0.01-0.66$ & 0.020 \\
\hline \multicolumn{7}{|l|}{ No. of eHCC } \\
\hline \multicolumn{7}{|l|}{ One } \\
\hline Two or more & 0.30 & $0.12-0.75$ & 0.009 & & & \\
\hline \multicolumn{7}{|c|}{ Presence of progressed HCC } \\
\hline \multicolumn{7}{|l|}{ No } \\
\hline Yes & 0.86 & $0.34-2.17$ & 0.742 & & & \\
\hline \multicolumn{7}{|c|}{ Child-Pugh score } \\
\hline$A$ & & & 0.204 & & & \\
\hline B & 0.61 & $0.21-1.80$ & 0.374 & & & \\
\hline C & 0.13 & $0.01-1.53$ & 0.105 & & & \\
\hline \multicolumn{7}{|l|}{ ALBI grade } \\
\hline 1 & & & 0.636 & & & \\
\hline 2 & 0.96 & $0.37-2.49$ & 0.594 & & & \\
\hline 3 & 0.56 & $0.16-1.91$ & 0.354 & & & \\
\hline \multicolumn{7}{|c|}{ Hepatobiliary phase } \\
\hline \multicolumn{7}{|l|}{ EnQS } \\
\hline 0 & & & 0.041 & & & \\
\hline 1 & 4.17 & $0.66-26.29$ & 0.129 & & & \\
\hline 2 & 6.84 & $1.50-31.18$ & 0.013 & & & \\
\hline \multicolumn{7}{|l|}{ EXQS } \\
\hline 0 & & & 0.319 & & & \\
\hline 1 & 2.00 & $0.20-19.91$ & 0.554 & & & \\
\hline 2 & 3.68 & $0.49-27.64$ & 0.205 & & & \\
\hline \multicolumn{7}{|l|}{ PVsQS } \\
\hline 0 & & & 0.204 & & & \\
\hline 1 & 1.83 & $0.20-16.51$ & 0.589 & & & \\
\hline 2 & 3.90 & $0.52-29.42$ & 0.187 & & & \\
\hline
\end{tabular}


Table 3. Continued

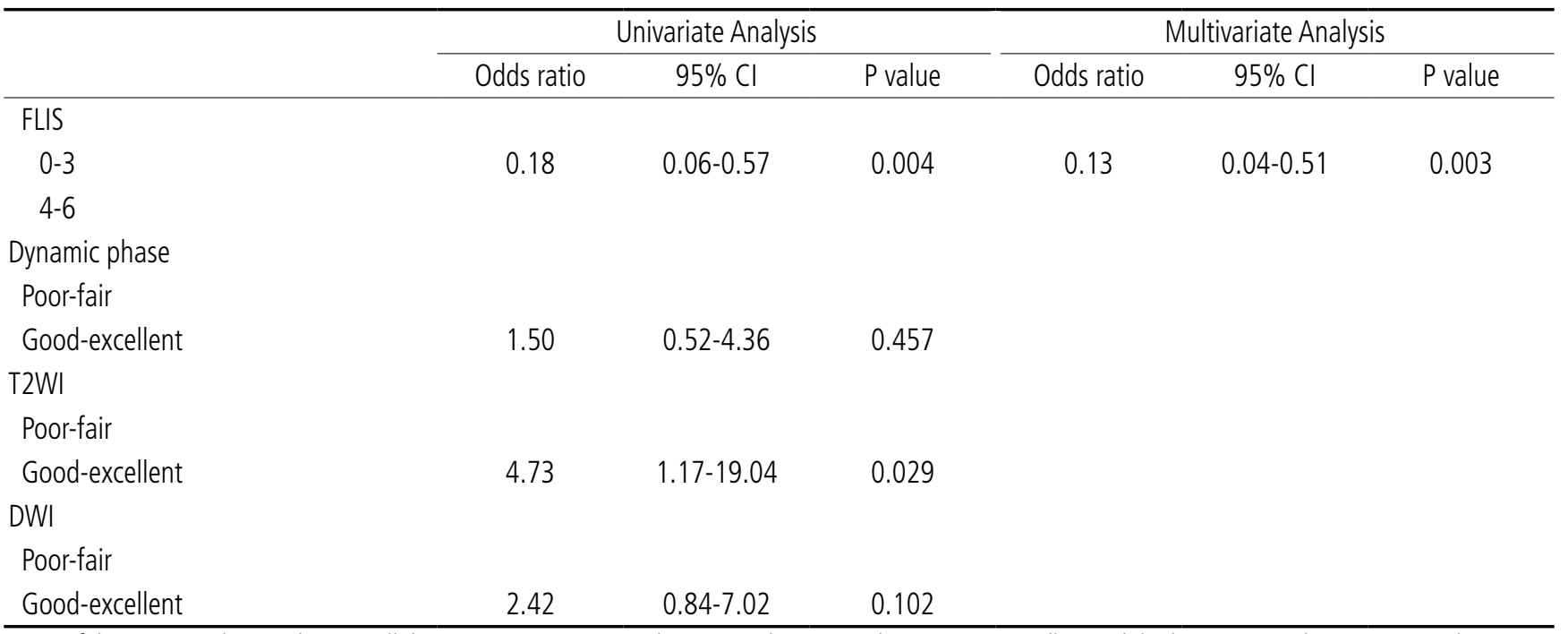

$\mathrm{Cl}$, confidence interval; HCC, hepatocellular carcinoma; eHCC, early HCC; LT, liver transplantation; ALBI, albumin-bilirubin; EnQS, enhancement quality score; ExQS, excretion quality score; PVsQS, portal vein sign quality score; FLIS, functional liver imaging score; T2WI, T2-weighted imaging; DWI, diffusion-weighted imaging.

be considered pseudolesions, because they frequently show isoattenuation or isointensity on late dynamic images.

Our results showed diffusion restriction in just $22 \%$ of the detected lesions, comparable with $21 \%$ in a study by Kim et al. (17). Moreover, diffusion restriction was seen in only one eHCC without APHE, suggesting that there is limited additional value in using DWI for detecting eHCC. Notably, in our series, capsule appearance was present in $8 \%$ of eHCCs, similar to a previous report $(9.5 \%, 4 / 42)$ (17). The presence of capsule appearance on EOB-MRI might be extraordinary because eHCCs are, histologically, vaguely nodular tumors with indistinct margins, lacking a tumor capsule (33). However, in the setting of advanced cirrhosis such as explanted livers, eHCC may show a more distinctly nodular appearance because of surrounding cirrhotic septa, not tumor capsule $(3,34,35)$. Therefore, the capsule appearance on EOB-MRI may be indicative of a pseudocapsule, caused by the retention of contrast material at lesion margins(30). In addition, eHCCs frequently showed well-defined margins on MRI, especially on HBP images, probably because of the higher tissue contrast on these images.

Strengths of our study include both the prospective and retrospective evaluation of eHCC detection sensitivity. In the prospectively acquired data from preoperative MRI reports, approximately $10 \%(17 / 173)$ of lesions were missed compared with that in retrospective review, which may reflect more realistic data. The retrospective per-lesion detection sensitivity $(78 \%)$ in our study was comparable to that in a recent study by Kim et al. (71-79\%) based on retrospective analysis (17).

We also evaluated factors related to the failure of preoperative detection. First, as expected, false-negative detection was affected by lesion size; eHCCs $<1 \mathrm{~cm}$ (21/56 [37\%]) were not preoperatively identified, comprising $55 \%(21 / 38)$ of the total false-negative results. Comparatively, only $3 \%(1 / 38)$ of false-negative detection occurred in eHCCs $\geq 2 \mathrm{~cm}$. Second, a history of HCC treatment increased the false-negative detection of eHCCs, probably due to hemodynamic alteration or parenchymal architectural distortion of the liver associated with treatment. Third, the higher false-negative detection rate in patients with multiple HCCs may be attributed to the satisfaction of search error $(36,37)$. Finally, the quality of HBP enhancement (determined by FLIS) was independently associated with the false-negative detection of eHCCs. Given that the most sensitive imaging feature for the detection of eHCCs was HBP hypointensity, it may be expected that poor HBP quality leads to falsenegative detection. Conversely, other laboratory or clinical parameters of hepatic function (including Child-Pugh class 
or $\mathrm{ALBI}$ grade), image quality of $\mathrm{T} 2 \mathrm{WI}, \mathrm{DWI}$, and dynamic imaging were not independent factors associated with the false-negative detection of eHCCs on multivariate analysis.

This study also has limitations. First, it may have inherent selection bias due to the retrospective design. For example, as we only included patients who underwent surgical resection, their hepatic function was relatively good, possibly limiting evaluation of the association between hepatic function and false-negative detection. Second, calculation of prospective eHCC detection sensitivity was based on original radiological reports; however, this approach may have provided more realistic results compared to those based on just retrospective review. Third, although the whole liver was available as a reference standard in transplanted patients, the remnant liver in the resection group could not be evaluated. Finally, despite extensive efforts to correlate preoperative MRI with pathological specimens, accurate lesion-bylesion matching was occasionally difficult, especially for explanted livers.

In conclusion, our study showed that histologically defined eHCCs are most commonly seen as HBP hypointensity. Arterial phase hyperenhancement and washout appearance are seen more frequently than fatty change, diffusion restriction, and capsule appearance. Detection sensitivity may be affected by lesion size, history of HCC treatment, number of HCCS, and hepatobiliary enhancement.

ORCID: Nieun Seo: https://orcid.org/0000-0001-8745-6454; Myeong-Jin Kim: https://orcid.org/0000-0001-7949-5402; Young Nyun Park: https://orcid.org/00000003-0357-7967; Mi-Suk Park: https://orcid.org/0000-0001-5817-2444; JinYoung Choi: https://orcid.org/0000-0002-9025-6274; Yong Eun Chung: https:// orcid.org/0000-0003-0811-9578

\section{References}

1. Tang A, Hallouch O, Chernyak V, Kamaya A, Sirlin CB. Epidemiology of hepatocellular carcinoma: target population for surveillance and diagnosis. Abdom Radiol (NY) 2018:43:13-25.

2. Zech CJ, Ba-Ssalamah A, Berg T, Chandarana H, Chau GY, Grazioli L, et al. Consensus report from the 8th International Forum for Liver Magnetic Resonance Imaging. Eur Radiol 2020;30:370-382.
3. Park YN. Update on precursor and early lesions of hepatocellular carcinomas. Arch Pathol Lab Med 2011;135:704-715.

4. Oikawa T, Ojima H, Yamasaki S, Takayama T, Hirohashi S, Sakamoto M. Multistep and multicentric development of hepatocellular carcinoma: histological analysis of 980 resected nodules. J Hepatol 2005;42:225-229.

5. Kojiro M. Pathology of early hepatocellular carcinoma: progression from early to advanced. Hepatogastroenterology 1998;45 Suppl 3:1203-1205.

6. International Consensus Group for Hepatocellular NeoplasiaThe International Consensus Group for Hepatocellular N. Pathologic diagnosis of early hepatocellular carcinoma: a report of the international consensus group for hepatocellular neoplasia. Hepatology 2009;49:658-664.

7. Takayama T, Makuuchi M, Hirohashi S, Sakamoto M, Yamamoto J, Shimada K, et al. Early hepatocellular carcinoma as an entity with a high rate of surgical cure. Hepatology 1998;28:1241-1246.

8. Inoue K, Takayama T, Higaki T, Watanabe Y, Makuuchi M. Clinical significance of early hepatocellular carcinoma. Liver Transpl 2004;10:S16-19.

9. Kudo M. Early hepatocellular carcinoma: definition and diagnosis. Liver Cancer 2013;2:69-72.

10. An C, Choi GH, Lee HS, Kim MJ. Assessment of preoperative magnetic resonance imaging staging in patients with hepatocellular carcinoma undergoing resection compared with the seventh American Joint Committee on Cancer System. Invest Radiol 2012;47:634-641.

11. Rhee H, Kim MJ, Park MS, Kim KA. Differentiation of early hepatocellular carcinoma from benign hepatocellular nodules on gadoxetic acid-enhanced MRI. Br J Radiol 2012;85:e837-844.

12. Chon YE, Jung KS, Kim MJ, Choi JY, An C, Park JY, et al. Predictors of failure to detect early hepatocellular carcinoma in patients with chronic hepatitis B who received regular surveillance. Aliment Pharmacol Ther 2018;47:1201-1212.

13. Tsuboyama $T$, Onishi $H$, Kim T, Akita $H$, Hori $M$, Tatsumi $M$, et al. Hepatocellular carcinoma: hepatocyteselective enhancement at gadoxetic acid-enhanced MR imaging--correlation with expression of sinusoidal and canalicular transporters and bile accumulation. Radiology 2010;255:824-833.

14. Hwang GJ, Kim MJ, Yoo HS, Lee JT. Nodular hepatocellular carcinomas: detection with arterial-, portal-, and delayed- 
phase images at spiral CT. Radiology 1997;202:383-388.

15. Sano K, Ichikawa T, Motosugi U, Sou H, Muhi AM, Matsuda $M$, et al. Imaging study of early hepatocellular carcinoma: usefulness of gadoxetic acid-enhanced MR imaging. Radiology 2011;261:834-844.

16. Rhee H, Kim MJ, Park YN, Choi JS, Kim KS. Gadoxetic acidenhanced MRI findings of early hepatocellular carcinoma as defined by new histologic criteria. J Magn Reson Imaging 2012;35:393-398.

17. Kim BR, Lee JM, Lee DH, Yoon JH, Hur BY, Suh KS, et al. Diagnostic Performance of Gadoxetic Acid-enhanced Liver MR Imaging versus Multidetector CT in the Detection of Dysplastic Nodules and Early Hepatocellular Carcinoma. Radiology 2017;285:134-146.

18. Ichikawa T, Sano K, Morisaka H. Diagnosis of Pathologically Early HCC with EOB-MRI: Experiences and Current Consensus. Liver Cancer 2014;3:97-107.

19. Kim YY, An C, Kim S, Kim MJ. Diagnostic accuracy of prospective application of the Liver Imaging Reporting and Data System (LI-RADS) in gadoxetate-enhanced MRI. Eur Radiol 2018;28:2038-2046.

20. Piana G, Trinquart L, Meskine N, Barrau V, Beers BV, Vilgrain $V$. New MR imaging criteria with a diffusion-weighted sequence for the diagnosis of hepatocellular carcinoma in chronic liver diseases. J Hepatol 2011;55:126-132.

21. Park MS, Kim S, Patel J, Hajdu CH, Do RK, Mannelli L, et al. Hepatocellular carcinoma: detection with diffusion-weighted versus contrast-enhanced magnetic resonance imaging in pretransplant patients. Hepatology 2012;56:140-148.

22. Renzulli M, Biselli M, Brocchi S, Granito A, Vasuri F, Tovoli $F$, et al. New hallmark of hepatocellular carcinoma, early hepatocellular carcinoma and high-grade dysplastic nodules on Gd-EOB-DTPA MRI in patients with cirrhosis: a new diagnostic algorithm. Gut 2018;67:1674-1682.

23. Child CG, Turcotte JG. Surgery and portal hypertension. Major Probl Clin Surg 1964;1:1-85.

24. Pugh RN, Murray-Lyon IM, Dawson JL, Pietroni MC, Williams R. Transection of the oesophagus for bleeding oesophageal varices. Br J Surg 1973;60:646-649.

25. Johnson PJ, Berhane S, Kagebayashi C, Satomura S, Teng $M$, Reeves $H L$, et al. Assessment of liver function in patients with hepatocellular carcinoma: a new evidence-based approach-the ALBI grade. J Clin Oncol 2015;33:550-558.

26. Roskams T, Kojiro M. Pathology of early hepatocellular carcinoma: conventional and molecular diagnosis. Semin Liver Dis 2010;30:17-25.

27. Bastati N, Wibmer A, Tamandl D, Einspieler H, Hodge $J C$, Poetter-Lang $S$, et al. Assessment of Orthotopic Liver Transplant Graft Survival on Gadoxetic Acid-Enhanced Magnetic Resonance Imaging Using Qualitative and Quantitative Parameters. Invest Radiol 2016;51:728-734.

28. American College of Radiology. Liver imaging reporting and data system (LI-RADS). American College of Radiology. Web site. https://www.acr.org/Clinical-Resources/Reporting-andData-Systems/LI-RADS/CT-MRI-LI-RADS-v2017. Accessed June 1, 2017.

29. An C, Rhee H, Han K, Choi JY, Park YN, Park MS, et al. Added value of smooth hypointense rim in the hepatobiliary phase of gadoxetic acid-enhanced MRI in identifying tumour capsule and diagnosing hepatocellular carcinoma. Eur Radiol 2017;27:2610-2618.

30. Ishigami K, Yoshimitsu K, Nishihara Y, Irie H, Asayama $Y$, Tajima $T$, et al. Hepatocellular carcinoma with a pseudocapsule on gadolinium-enhanced MR images: correlation with histopathologic findings. Radiology 2009;250:435-443.

31. Landis JR, Koch GG. The measurement of observer agreement for categorical data. Biometrics 1977;33:159174.

32. Kitao A, Matsui O, Yoneda N, Kozaka K, Shinmura R, Koda $\mathrm{W}$, et al. The uptake transporter OATP8 expression decreases during multistep hepatocarcinogenesis: correlation with gadoxetic acid enhanced MR imaging. Eur Radiol 2011;21:2056-2066.

33. Desmet VJ. East-West pathology agreement on precancerous liver lesions and early hepatocellular carcinoma. Hepatology 2009:49:355-357.

34. Roncalli M, Park YN, Di Tommaso L. Histopathological classification of hepatocellular carcinoma. Dig Liver Dis 2010;42 Suppl 3:S228-234.

35. Theise ND, Park YN, Kojiro M. Dysplastic nodules and hepatocarcinogenesis. Clin Liver Dis 2002;6:497-512.

36. Waite S, Scott J, Gale B, Fuchs T, Kolla S, Reede D. Interpretive Error in Radiology. AJR Am J Roentgenol 2017;208:739-749.

37. Degnan AJ, Ghobadi EH, Hardy P, Krupinski E, Scali EP, Stratchko $L$, et al. Perceptual and Interpretive Error in Diagnostic Radiology-Causes and Potential Solutions. Acad Radiol 2019;26:833-845. 


\title{
조직학적 조기 간세포암의 가도세틱산 조영증강영상과 확산강조 자기공명영상 소견
}

\author{
서니은 ${ }^{1}$, 김명진', 박영년 ${ }^{2}$, 박미숙', 최진영', 정용은 \\ ${ }^{1}$ 연세대학교 의과대학 세브란스병원 영상의학과 \\ ${ }^{2}$ 연세대학교 의과대학 세브란스병원 병리과
}

목 적: 조직학적 조기 간세포암의 가도세틱산 조영증강 영상과 확산강조 자기공명영상 소견을 살펴보고자 한다.

대상과 방법: 2006년 1월부터 2017년 9월까지 가도세틱산 조영증강 영상과 확산강조 자기공명영상을 시행 후 수술 로 조기 간세포암으로 진단된 환자 119 명의 173 개의 병변이 연구대상으로 포함되었다. 수술 전 발견된 조기 간세포암 의 영상 소견을 2 명의 영상의학과 전문의가 후향적으로 분석하였다. 조기 간세포암의 가음성 진단과 관련된 임상적, 영상의학적 요인을 평가하였다.

결 과: 119 명의 173 개 조기 간세포암 중에서 78 명의 118 개 (68\%)의 조기 간세포암이 수술 전 영상에서 판독되었다. 후향적 리뷰 후에 13 명의 17 개 조기 간세포암이 추가로 발견되었으며, 병변별 진단 민감도는 $78 \%$ (135/173)였다. 따 라서 91 명 환자의 135 개의 조기 간세포암의 영상소견이 분석되었다. 대부분의 조기 간세포암은 간담도기 저신호강 도를 보였다 $(90 \%, 122 / 135)$. 동맥기 과조영증강, 씻김 현상 (washout), 캡슐 양상은 각각 68 (50\%), 79 (59\%), and 11 (8\%)개 병변에서 관찰되었다. 확산 제한과 지방 변화는 30 (22\%), 39 (29\%)개에서 관찰되었다. 대부분의 조기 간 세포암은 T1 및 T2 강조영상에서 동일 신호강도를 보였다 (80 [59\%], 89 [66\%]). 가음성 진단은 작은 병변 크기 (< $1 \mathrm{~cm}$ ), 간세포암 치료 기왕력 (odds ratio, 0.34 [95\% 신뢰구간, 0.13-0.92]), 간세포암 개수 ( $\geq 2$; odds ratio, 0.08 [0.01-0.66]), 낮은 간기능영상 점수 (<4; odds ratio, 0.13 [0.04-0.51])와 유의한 관련이 있었다.

결 론: 조직학적 조기 간세포암은 전형적으로 간담도기 영상 저신호강도를 보인다. 조기 간세포암의 진단 민감도는 병변의 크기, 간세포암 치료 기왕력, 간세포암 개수, 그리고 간담도기 조영증강에 영향을 받을 수 있다. 